\title{
Ethnomedicinal Knowledge on Water Purification in Selected Rural Areas of Ethiopia
}

\author{
Moa Megersa, Abebe Beyene, Argaw Ambelu, \\ Zeleke Alebachew, and Ludwig Triest
}

\section{Research}

\begin{abstract}
Plants have been used for water purification dating back to perhaps 2000 BC as noted in Egyptian inscriptions. Plant coagulants have the potential to serve as alternative water treatment agents especially in rural areas. Hence this study aimed to examine four promising plants and their uses as local coagulants for purification of turbid water in order to tackle rural quality water problems. Semistructured interviews, focus group discussions, market surveys, and observation were used to gather information from three rural areas. Jar test experiments were carried out for treatment of high (209 NTU), medium (63 NTU), and low level (26 NTU) turbidity with the flocculent dosages of $0.03 \mathrm{~g} / \mathrm{L}$ of powdered plant material. The four plant species used for treatment of turbid water were Maerua subcordata (Gilg) DeWolf, Moringa stenopetala (Baker f.) Cufod., Sansevieria ehrenbergii Schweinf. ex Baker, and Sansevieria forskaliana (Schult. \& Schult.f.) Hepper \& J.R.I.Wood. The finding shows that societies in each study area still depend on plant species for purification of turbid surface water. Coagulation tests revealed that tubers of $M$. subcordata and seeds of $M$. stenopetala were able to remove turbidity up to $97 \%$ at high turbidity levels and performance was better than leaves of $S$. ehrenbergil and $S$. forskaliana. Complementing traditional water treatment knowledge with coagulation tests and purification of the specific protein coagulant could help to identify appropriate solutions for rural people with difficulty preparing purified water.
\end{abstract}

\section{Introduction}

Egyptian inscriptions afford the earliest recorded knowledge of plant materials used for water treatment, dating back perhaps to $2000 \mathrm{BC}$ in addition to boiling and filtration (Fahey 2005). This is part of a larger body of tradition- al plant knowledge that has been developed for resource management (Ellen \& Harris 2000, Raedeke \& Rikoon 1997). Traditional knowledge is described as a cumulative body of knowledge, practice, and belief, evolving by adaptive processes and handed down through generations by cultural transmission, about the relationship of living beings with one another and with their environment (Berkes et al. 2003).

There is evidence to suggest that communities in the developing world have used plant-based materials as one strategy for purifying surface drinking water (Miller et al. 2008). For instance, Strychnos potatorum L.f. was used as a water treatment agent between the $14^{\text {th }}$ and $15^{\text {th }}$ centuries BC in India (Shultz \& Okun 1984). Zea mays L. was used as a settling agent by sailors in the $16^{\text {th }}$ and $17^{\text {th }}$ centuries (Pritchard et al. 2009).

\section{Correspondence}

Moa Megersa, Department of Environmental Health Science and Technology, Jimma University P.O.BOX 378, Jimma, ETHIOPIA, Plant Biology and Nature Management (APNA), Vrije Universiteit Brussel, Pleinlaan 2, B-1050, Brussels, BELGIUM. moamegersa78@gmail. com

Abebe Beyene, Argaw Ambelu, Department of Environmental Health Science and Technology, Jimma University P.O.BOX 378, Jimma, ETHIOPIA.

Zeleke Alebachew, Ethiopian Health and Nutrition Research Institute (EHNRI), Gulele Sub City, Addis Ababa, ETHIOPIA.

Ludwig Triest Plant Biology and Nature Management (APNA), Vrije Universiteit Brussel, Pleinlaan 2, B-1050, Brussels, BELGIUM.

Ethnobotany Research \& Applications 14:393-403 (2015)

\section{Published: 22 December 2015}


Inadequate water quality services and sanitation to the rural poor are among the most serious challenges facing developing countries (Marobhe et al. 2007). At present, about 780 million people are without access to improved sources of drinking water, mainly in Sub-Saharan Africa (UNICEF/WHO 2012).

Ethiopia is ranked among the lowest to have accessible quality water supply in Sub-Saharan Africa (UNICEF/ WHO 2012). While access has increased with funding from external aid, especially associated with the Millennium Development Goals (MDG) targeted for completion in 2015, much still remains to be done to minimize the share of people without access to water and sanitation in the post-MDG era. According to the report of UNICEF and WHO (2012), access to improved water in urban areas reaches up to $97 \%$, but only $34 \%$ of rural populations get improved water. The unavailability of safe drinking water in most rural locations is one of the main causes of diarrhea among children under the age of five (CSA 2006).

Although the problem of safe water remains a challenge in rural areas, local people have also developed traditional water treatment knowledge for drinking and other domestic purposes. The use of traditional knowledge in treating turbid water in rural communities has been reported (Cheserek 2005, Jahn \& Dirar 1979, Marobhe et al. 2007, Sutherland et al. 1989, Yongabi et al. 2011) with seeds being widely used parts for water treatment (Megersa et al. 2014). For instance, the seed powder from Arachis hypo- gaea L., Carica papaya L., Garcinia kola Heckel, Maerua edulis (Gilg \& Gilg-Ben.) DeWolf, Moringa oleifera Lam., Parkinsonia aculeata L., Persea americana Mill., Vicia faba L., Vigna subterranea (L.) Verdc., and Vigna unguiculata (L.) Walp. are used for purification of water in rural areas of Africa. Those plant species are able to reduce turbidity up to $95 \%$, which is comparable to inorganic coagulant (alum). However, the determination of optimum dose, release of organic matter, bacterial re-growth, toxicity, and large scale applicability were stated as primary drawbacks of natural coagulants.

A comprehensive analysis of available plant-based coagulants in Ethiopia is still non-existent despite their great relevance for development of point-of-use water treatment in rural areas. Therefore, the aim of this study was to identify indigenous knowledge of plant species used for purification of turbid water in rural areas of Ethiopia and to test their coagulation and flocculation ability. The implied hypothesis is that one or more plants used for this purpose is effective.

\section{Study area}

The study was conducted in Arbaminch, Jinka and Konso districts located in South Nations Nationalities and Peoples Regional state and in Yabello District located in Oromia National Regional State (Figure 1). The area is located within an altitudinal range of 1300-3140 m.a.s.I.

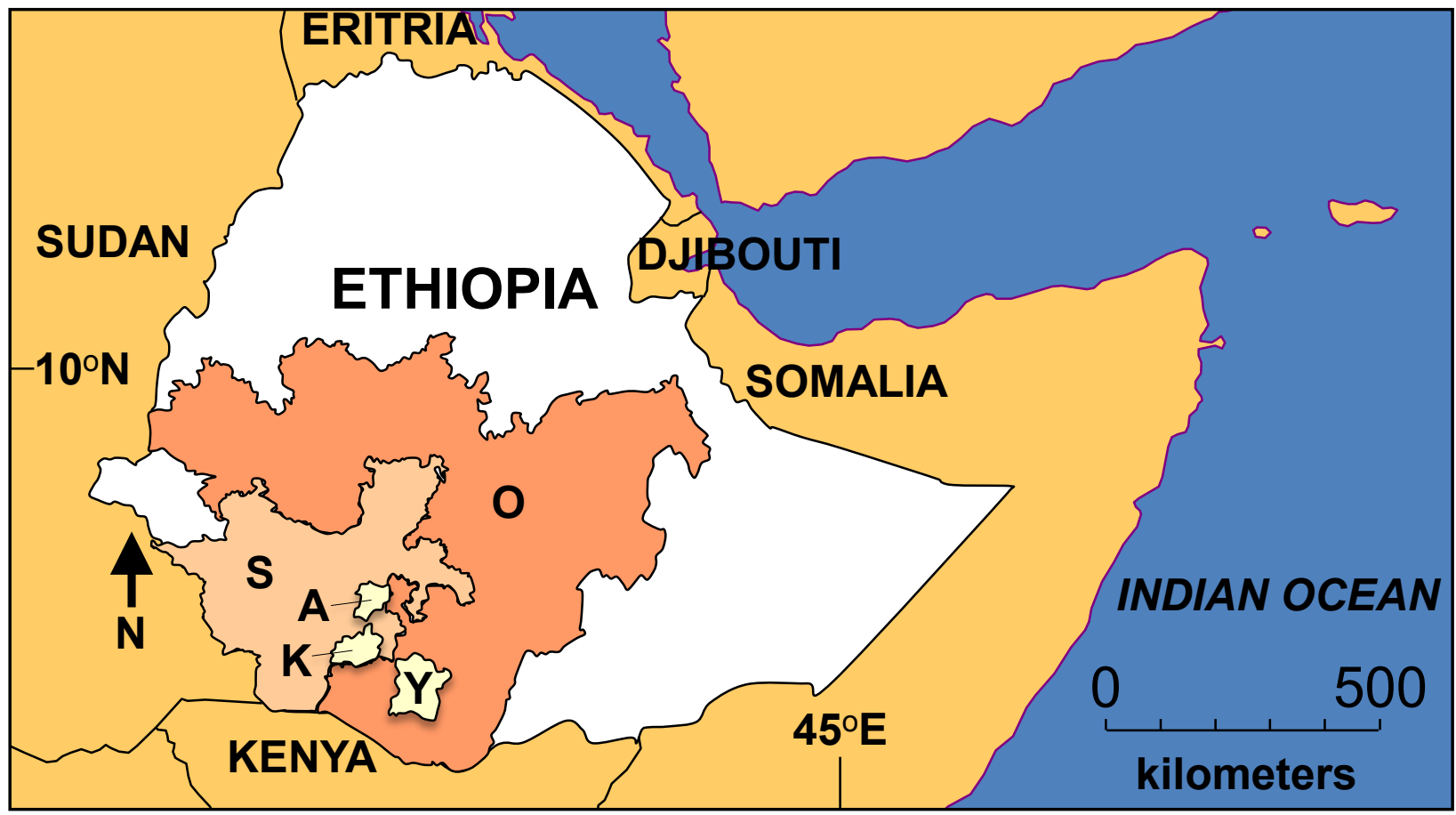

Figure 1. Study sites in (A) Arbaminch Jinka District and (K) Konso District, located in (S) South Nations Nationalities and Peoples Regional State, and (Y) Yabello District located in (O) Oromia National Regional State, Ethiopia. 


\section{Megersa et al. - Ethnomedicinal Knowledge on Water Purification in Selected 395 Rural Areas of Ethiopia}

Based on the 2007 population and housing census (CSA 2007), the Konso District has a population of 235,087 , of which about $96 \%$ are living in rural areas. Jinka is found in Bako Gazer District, Debub Omo Zone. The district has 210,557 people, of which about $85 \%$ are living in rural areas. Arbaminch rural district has a population of 164,529 of which none are urban dwellers (CSA 2007). The population of Yaballo District is projected to be 82,443 with $63,968(77.5 \%)$ living in rural areas.

\section{Medical services in the district}

As in many developing regions, the majority of people live in rural areas where modern health services are minimal. However, health services are increasing over the past ten years. The top ten diseases reported within the three study districts are respiratory infections, malaria, gastritis, intestinal parasites, dysentery, skin infections, anemia, eye infections, tonsillitis, and urinary tract infections. Of these diseases, intestinal parasites and dysentery are water-borne (DHO n.d.).

\section{Availability of drinking water in the districts}

The main sources of drinkable water in the study area are rivers, spring water, and ground water, as well as ponds and streams that are available during the rainy season. Woyito River is a source of drinking water for Datane people (Jinka and Konso districts).

Ground water is rarely used but is promoted with the help of NGOs such as SOS Children's Villages International and Act For Peace. Since it is hard to get water at less than 1-meter depth, it is difficult for individuals to access ground water. Ground water is mainly used during winter or summer when shortage of water occurs. At moments of high water potential a hand pump is used, whereas a motorized pump is used during periods of lower water potential.

During the rainy season, surface water is not safe to drink because of many suspended substances. Wuha agar, distributed by NGOs, is widely used in the districts to purify surface water. However, people lack awareness of its use and apply it for cattle ailments. Beyond this chemical treatment, people use their indigenous knowledge to purify turbid water.

\section{Methods}

\section{Site selection}

The four study sites were selected based on prior known traditional practices using locally available materials to purify polluted water. This was thought to be a very common practice in the areas.

\section{Ethnobotanical data collection}

Semi-structured interviews, observations, group discussion, and guided field walks (Cotton 1996, Martin 1995) were used. Key informants were selected purposively and systematically based on the recommendations of knowledgeable elders, local authorities, and development agents. The data were collected from September 2012 to June 2014 at different seasons.

Interviews and discussions were undertaken based on a checklist of questions prepared in English and translated to local languages of Amharic and Afaan Oromo. During an interview, the local name of each plant species, the part(s) used, dosage, methods of preparation, uses other than water treatment, and conservation status were recorded. Field observations were performed with the help of local guides to collect the plant species and method of treatment. The status, habit, habitat, and characteristics of the plants were recorded on site.

Discussions were conducted with 8 respondents on water quality problems in the area, source of impurities, and effectiveness of the plant species as alternative water treatment. Discussions were performed with a district health officer, water, mineral, and energy director, and district agricultural office directors. Knowledgeable elders were also included in the discussion. A market survey was also undertaken in Elwoye market which is held at Elwoye town (Yaballo District). Before collecting the data, written permission was obtained from the office of the district. Following this, the purpose of the study was explained to each informant, and verbal prior consent was obtained.

\section{Specimen collection and identification}

Preliminary identification was done at the site, and voucher specimens were stored at the National Herbarium of Ethiopia (Addis Ababa University).

\section{Preference ranking}

Preference ranking was conducted for evaluating the degree of preferences of plant species to treat turbid water following standard protocol (Martin 1995). According to this protocol, six selected key informants were invited to rank the four medicinal plant species that are used for water treatment. Values of 1 to 5 were used in this ranking ( 1 = least preferred, 2 = less used, 3 = good, $4=$ very good, 5 = most preferred).

\section{Coagulation test}

Plant materials of four species (Maerua subcordata, Moringa stenopetala, Sansevieria ehrenbergii, and Sansevieria forskaliana) were used to evaluate the coagulation (turbidity removal) potential at the laboratory of Environ- 
mental Health Science and Technology in Jimma University, Ethiopia. A practical test was conducted on natural surface water collected from Awetu River in Jimma town. The initial turbidity of the river was 26 (low), 63 (medium), and 209 (high) NTU for three experiments. The jar test apparatus was used in a coagulation and flocculation experiment whereby $0.03 \mathrm{~g} / \mathrm{L}$ of powdered plant materials were added into $1 \mathrm{~L}$ beakers containing the water samples at three turbidity levels. Turbidity changes were measured during the first six hours against positive and negative controls.

\section{Results and Discussion}

\section{Profiles of respondents}

A total of 50 informants (30 males and 20 females) were purposively selected. Demographically the informants, were $48 \%$ Protestant (24 people), 34\% Muslim (17), 12\% Wakefata (6), and $12 \%$ Orthodox (6). The majority of Protestant respondents were from Konso District whereas Muslims mainly were from Yaballo District. 90\% of informants (45 people) were illiterate, with $8 \%$ having completed elementary level courses (4), and $2 \%$ having attended up to college level (1).

\section{Source of water and types of impurities}

All of the respondents replied that they knew about types of impurities and that the major water pollutants in the area are pathogenic biological organisms, organic impurities, and turbidity. Turbidity-causing substances were reported by all informants.

The quality of water is generally determined by informants via visual inspection. About $97 \%$ of interviewees in Yabello District and Datane, Konso District, reported that the water they drink is of poor quality. We observed evidence of this. Only $3 \%$ of respondents replied that they drink water of medium quality.

\section{Water treatment techniques applied in the districts}

Local people of the study area used different methods to purify the water they drink: boiling (25\%), chemical disinfection with wuha agar (40\%), and locally available natural plant based coagulants (35\%). Boiling is preceded by filtering and mixing the boiled water with salt then cooling before drinking. Wuha agar, a chlorine-based solution, is widely distributed to the local people and therefore available for treatment of polluted water. In the study area, surface water treatment using naturally available materials (plant-based) was also widely practiced (Table 1).

\section{Plants used for water treatment in the study areas}

There were four reported plant species (Table 1) that have coagulating potential of turbid water and are used by local people. Local people prepare plant coagulants in different ways. The more detailed preparation methods are summarized in Table 2. The potential and use of those plants varied from area to area. Maerua subcordata was widely used in Datene and Jinka areas whereas $S$. ehrenbergii and S. forskaliana were used in Yaballo and Konso areas.

\section{Use of plants other than water treatment}

The reported plant species have uses other than water treatment value. For instance, $M$. stenopetala has multiple uses. The leaves are used as a food and sold in the market whereas roots are used for treatment of diseases. Sansevieria forskaliana and S. ehrenbergii are used as drought fodder for cattle. In addition, $S$. forskaliana is used as live fence, and $S$. ehrenbergii is used for making rope. Maerua subcordata has medicinal value; the roots are sold in Yaballo District and used for treating various ailments. No other parts of the plant are reported to be used for food consumption in the area.

Table 1. Plant species used for water treatment in rural Ethiopia. All four plants are wild-harvested, but M. stenopetala is also commonly cultivated in home gardens.

\begin{tabular}{|l|l|l|l|l|l|}
\hline Scientific name & Local name & Habit & $\begin{array}{l}\text { Part } \\
\text { used }\end{array}$ & Condition & Other uses \\
\hline $\begin{array}{l}\text { Maerua subcordata (Gilg) De Wolf } \\
\text { Capparidaceae }\end{array}$ & $\begin{array}{l}\text { Gulfe (Konso), Korsegeba, } \\
\text { Aberngab, Beryab (Afan Oro- } \\
\text { mo), Gulo (Gamogna) }\end{array}$ & Shrub & Tuber & $\begin{array}{l}\text { Dried or } \\
\text { Fresh }\end{array}$ & Medicine \\
\hline $\begin{array}{l}\text { Moringa stenopetala (Bakj) Cufod. } \\
\text { Moringaceae }\end{array}$ & $\begin{array}{l}\text { Shiferaw (Amargna), Haleko } \\
\text { (Konso, Gamo) }\end{array}$ & Tree & Seed & Dried & $\begin{array}{l}\text { Medicine, } \\
\text { Food }\end{array}$ \\
\hline $\begin{array}{l}\text { Sansevieria ehrenbergii Schwein- } \\
\text { furth ex Baker } \\
\text { Dracanaceae }\end{array}$ & Chake (Afan Oromo, Konso) & Shrub & Leaf & Fresh & $\begin{array}{l}\text { Drought } \\
\text { fodder, Rope }\end{array}$ \\
\hline $\begin{array}{l}\text { Sansevieria forskaliana (Schult. \& } \\
\text { Schult.f.) Hepper \& J.R.I.Wood } \\
\text { Dracanaceae }\end{array}$ & $\begin{array}{l}\text { Alge (Afan Oromo), Algita (Kon- } \\
\text { so), Algete (Amargna) }\end{array}$ & Shrub & Leaf & Fresh & $\begin{array}{l}\text { Drought } \\
\text { fodder }\end{array}$ \\
\hline
\end{tabular}




\section{Megersa et al. - Ethnomedicinal Knowledge on Water Purification in Selected Rural Areas of Ethiopia}

Table 2. Preparation of traditional water purifiers.

\begin{tabular}{|l|l|}
\hline Plant species & Preparation procedures \\
\hline $\begin{array}{l}\text { Maerua subcordata } \\
\text { (Gilg) DeWolf }\end{array}$ & $\begin{array}{l}\text { The shrub has a tuber beneath the ground which is found at about } 50-100 \mathrm{~cm} \text {. Local peo- } \\
\text { ple dig, wash, slice, and use the tuber for water purification by mixing the coagulant into } \\
\text { turbid surface water. One piece about } 50 \mathrm{~cm} \text { long can purify about } 200 \text { L of turbid water. } \\
\text { They used it either in solution form or as dry powder. Local people use the solution form } \\
\text { after grounding the dried tuber, and mix the fine powder with the turbid water. Once the tu- } \\
\text { ber is used it can be reused at least three times, though its capacity is gradually reduced. }\end{array}$ \\
\hline $\begin{array}{l}\text { Moringa stenopetala } \\
\text { (Baker f.) Cufod. }\end{array}$ & $\begin{array}{l}\text { The kernel is removed from the seed. The seeds are ground on stone to fine powder. The } \\
\text { powder is mixed with turbid water, making suspended matter settle. After settling, the water } \\
\text { is decanted to another bucket, ready for drinking and other domestic purposes. }\end{array}$ \\
\hline $\begin{array}{l}\text { Sansevieria } \\
\text { ehrenbergii Schweinf. } \\
\text { ex Baker }\end{array}$ & $\begin{array}{l}\text { Fresh leaves are crushed using stone to release exudates. While adding the crushed } \\
\text { leaves, the turbid water is mixed. Finally, the suspended matter settles, and the water is } \\
\text { ready for drinking. }\end{array}$ \\
\hline $\begin{array}{l}\text { Sansevieria forskaliana } \\
\text { (Schult. \& Schult.f.) } \\
\text { Hepper \& J.R.I.Wood }\end{array}$ & $\begin{array}{l}\text { Fresh leaves are crushed using stone. The crushed leaves are added to the turbid water } \\
\text { and stirred for few minutes. Finally, the suspended matter settles, and the water is ready } \\
\text { for drinking. }\end{array}$ \\
\hline
\end{tabular}

\section{Plant descriptions}

Maerua subcordata (Figure 2) is widespread along roadsides from Konso to Jinka around Woyito River in Dukana forest.

Moringa stenopetala (Figure 3 ) is widely grown in Arbaminch and Konso districts but rarely found in Yaballo District. Particularly in the Arba Minch and Konso areas, the local people cook the leaves of the M. stenopetala as food. The local people in the study areas cultivate the plant together with useful plants such as mango, avocado, and other crop plants. In Yaballo, the Agriculture Research Center is promoting the plant for food utilization and food security.

Sansevieria ehrenbergii (Figure 4) is widely grown in Yaballo and Konso. The plant is not cultivated yet and is found in the natural forests and along roadsides in Yaballo District.

Sansevieria forskaliana occurs commonly in Arbaminch Konso and Yaballo districts. The plant is not cultivated and found in the natural forests. Samples were collected from Elwoye of Yaballo District.

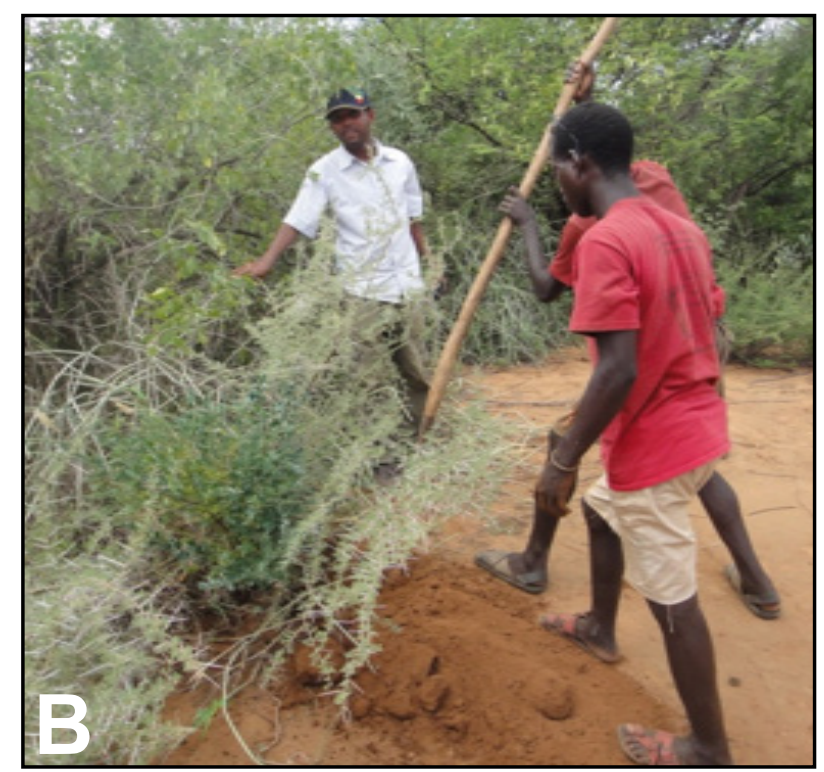

Figure 2. Maerua subcordata (Gilg) DeWolf shrub (A) and collection of its tuber (B). 


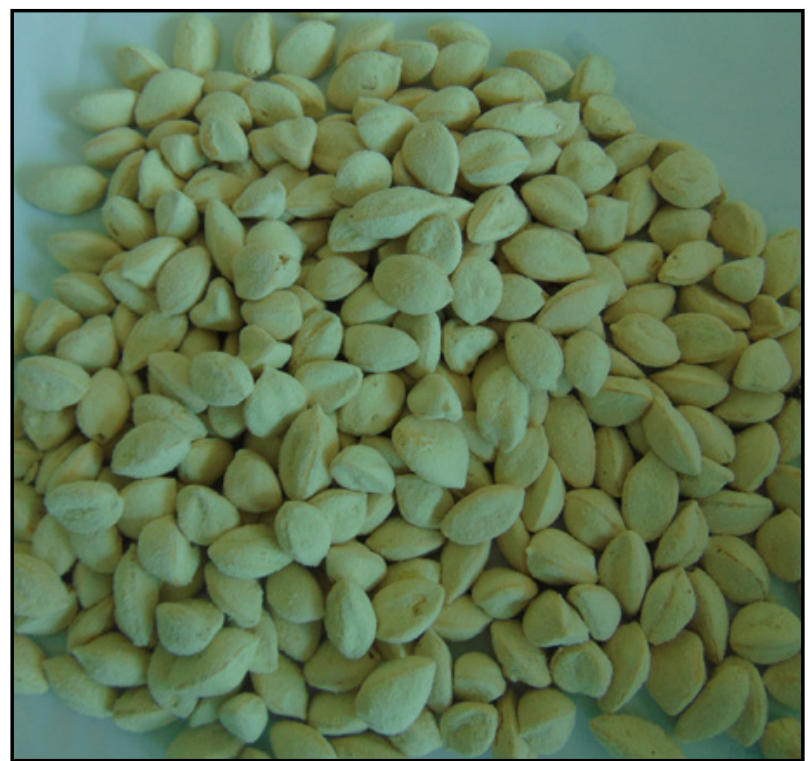

Figure 3. Moringa stenopetala (Baker f.) Cufod. seeds.

\section{Preference ranking of plant species}

Preference ranking of the four plant species showed that Maerua subcordata ranked first and was clearly delineated, indicating that it was perceived as the most effective in treating turbid water (Table 3 ).

\section{Evaluation of coagulation activity}

A coagulation test of the four plant species indicated that they do reduce turbidity. Accordingly, $M$. subcordata and $M$. stenopetala performed well on the three initial turbidity levels of 26,63 , and 209 NTU. Figures 6,7 , and 8 present the overall results of the coagulation/turbidity analysis.

\section{Discussion}

\section{Indigenous knowledge and practice on water treatment}

Results indicating wide knowledge of turbidity-causing substances is in agreement with those of a local communi-

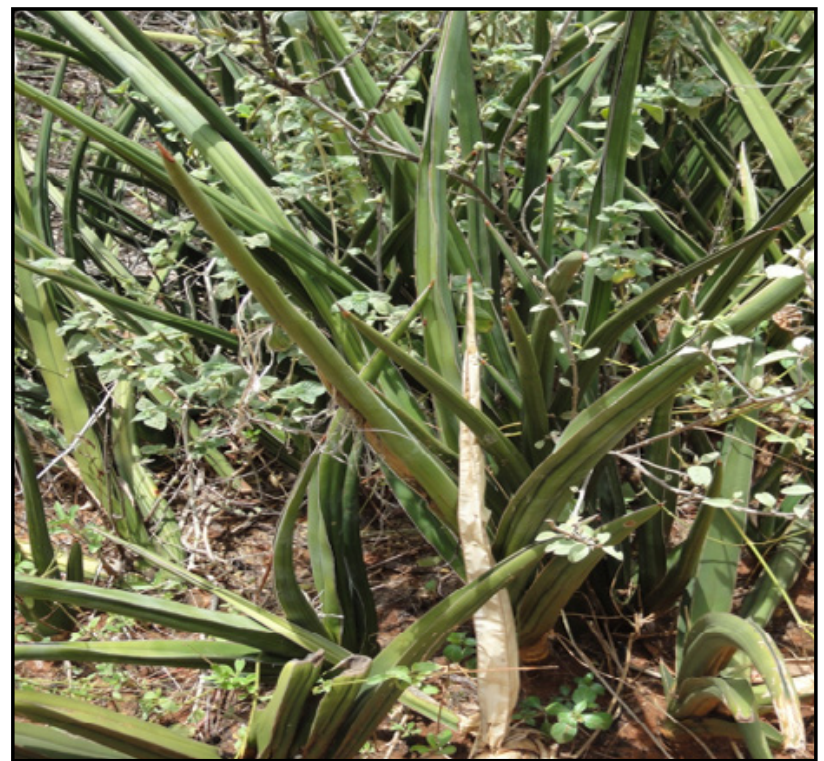

Figure 4. Sansevieria ehrenbergii Schweinf. ex Baker is a standing perennial with dark green leaves, usually $0.5-1.5$ $\mathrm{m}$ in length and $2.4-8.0 \mathrm{~cm}$ in width.

ty of Lavuvu catchment (South Africa) knowing how water became polluted (Nare et al. 2013). Toxic chemicals are not the cause in the area because of lack of sources such as factories; pastoralist livelihoods are potential sources in the case of Yaballo District where other forms of agriculture are not as much practiced. However, local people of Arbaminch Zuria Jinka and Konso districts rely on agroforestry and agriculture.

The local community acceptance of water to use in the study areas, in terms of turbidity, is much higher than the recommended maximum limit of turbidity set by WHO which is 5 NTU (Nare et al. 2013).

\section{Water treatment techniques applied in the districts}

Similar findings have been reported (Nare et al. 2013) in other parts of the world where local people use chlorinebased chemical treatment and plant materials to tackle turbid water. Uses of chlorine and plant material for household water treatment were also widely practiced in rural Ethiopia. Boiling is also the common household water

Table 3. Preference ranking of four selected medicinal plants used to treat turbid water. $5=$ most preferred.

\begin{tabular}{|l|c|c|c|c|c|c|c|c|}
\hline Plants used & \multicolumn{4}{|c|}{ Respondents } & \multirow{2}{*}{ Total } & \multirow{2}{*}{ Rank } \\
\cline { 2 - 6 } & A & B & C & D & E & F & & \\
\hline Maerua subcordata (Gilg) DeWolf & 5 & 5 & 4 & 3 & 5 & 5 & 27 & 1st \\
\hline Moringa stenopetala (Baker f.) Cufod. & 3 & 2 & 4 & 2 & 2 & 1 & 14 & 4th \\
\hline Sansevieria ehrenbergii Schweinf. ex Baker & 3 & 4 & 2 & 3 & 3 & 2 & 17 & 3rd \\
\hline Sansevieria forskaliana (Schult. \& Schult.f.) Hepper \& J.R.I.Wood. & 3 & 3 & 3 & 3 & 4 & 3 & 19 & 2nd \\
\hline
\end{tabular}




\section{Rural Areas of Ethiopia}

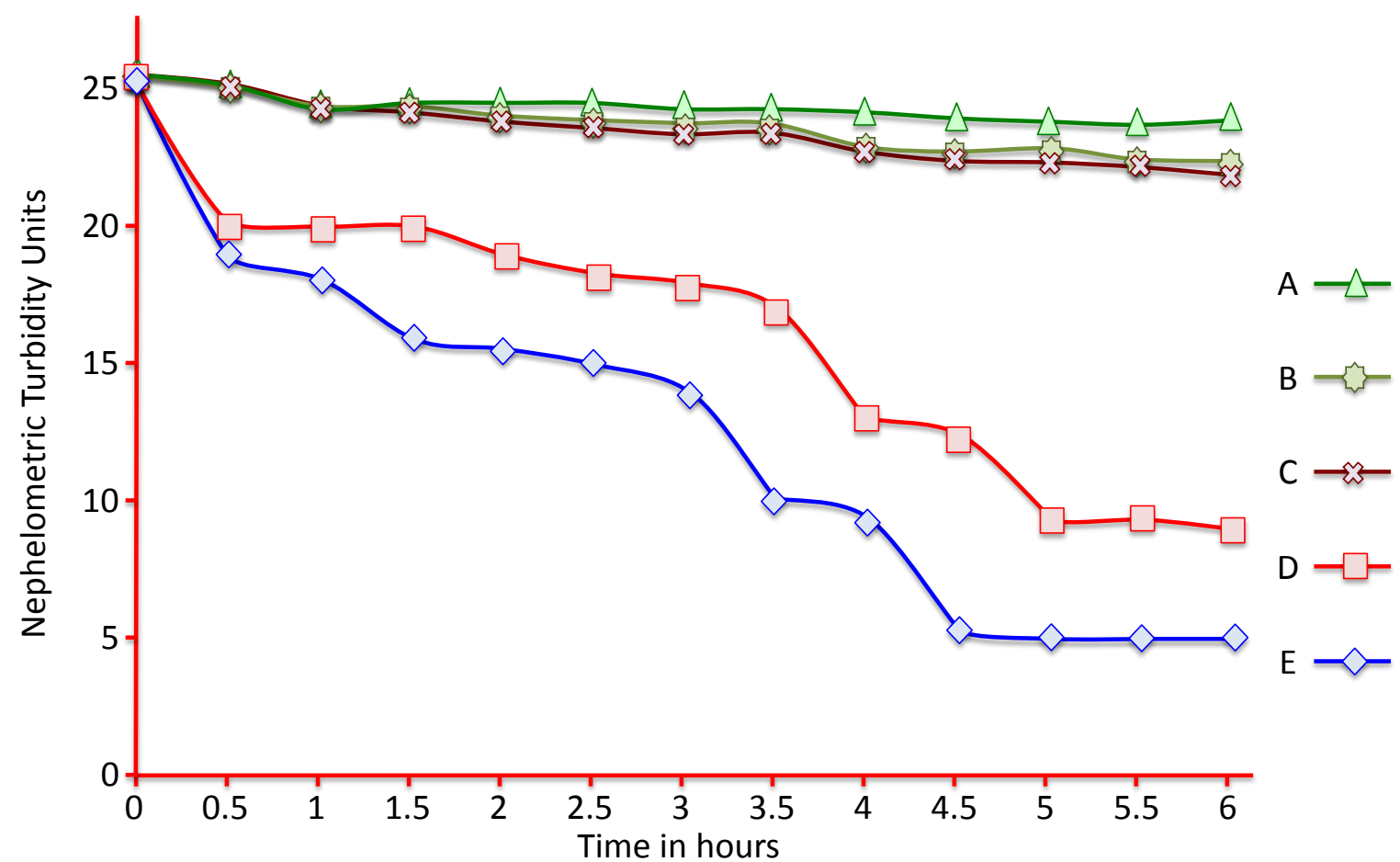

Figure 6. Coagulation test for removal of turbidity (initially 26 NTU) using a control (A) and four plants: (B) Sansevieria forskaliana (Schult. \& Schult.f.) Hepper \& J.R.I.Wood, (C) Sansevieria ehrenbergii Schweinf. ex Baker, (D) Moringa stenopetala (Baker f.) Cufod., and (E) Maerua subcordata (Gilg) DeWolf.

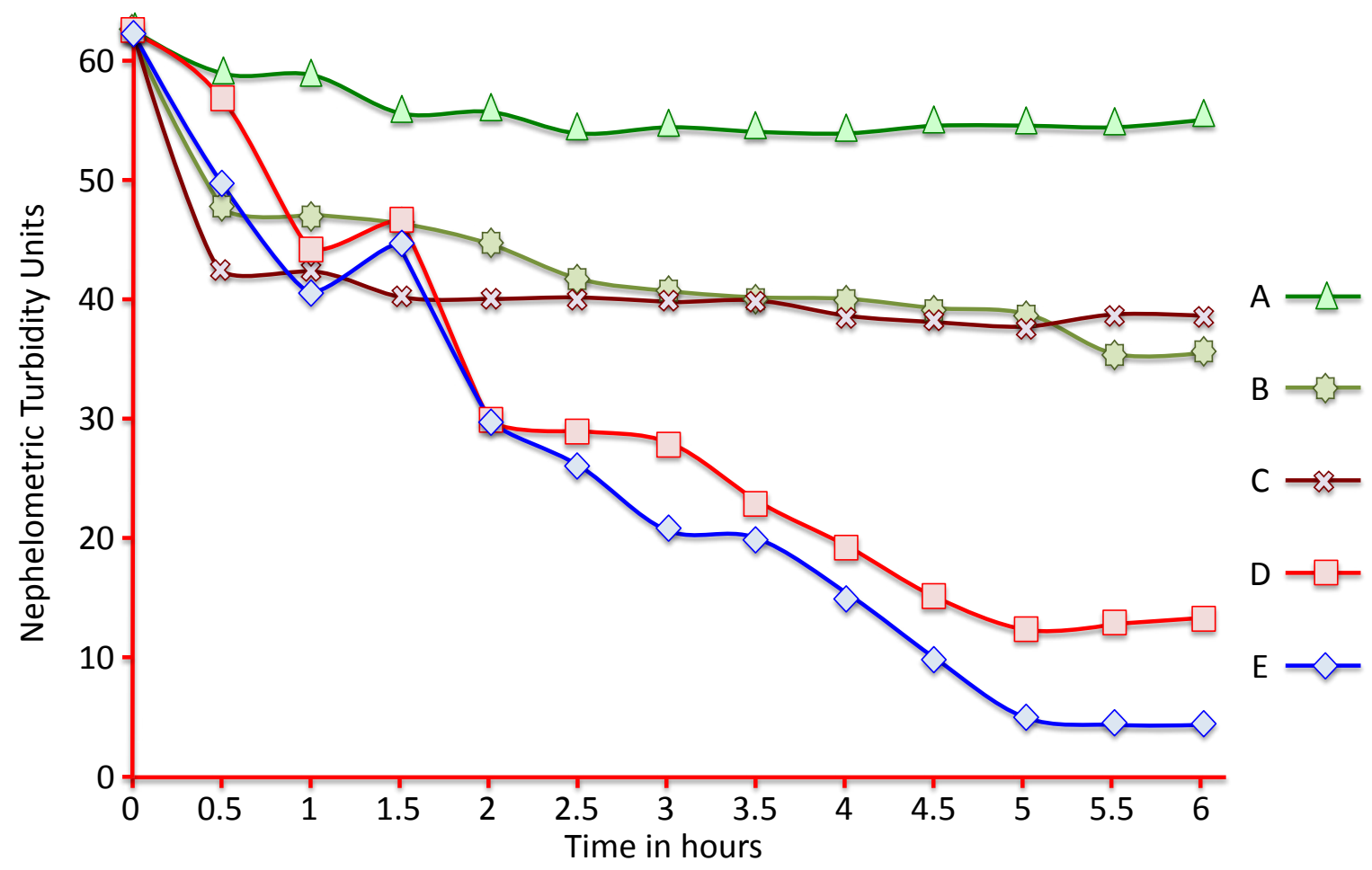

Figure 7. Coagulation test for removal of turbidity (initially 63 NTU) using a control (A) and four plants: (B) Sansevieria forskaliana (Schult. \& Schult.f.) Hepper \& J.R.I.Wood, (C) Sansevieria ehrenbergii Schweinf. ex Baker, (D) Moringa stenopetala (Baker f.) Cufod., and (E) Maerua subcordata (Gilg) DeWolf. 


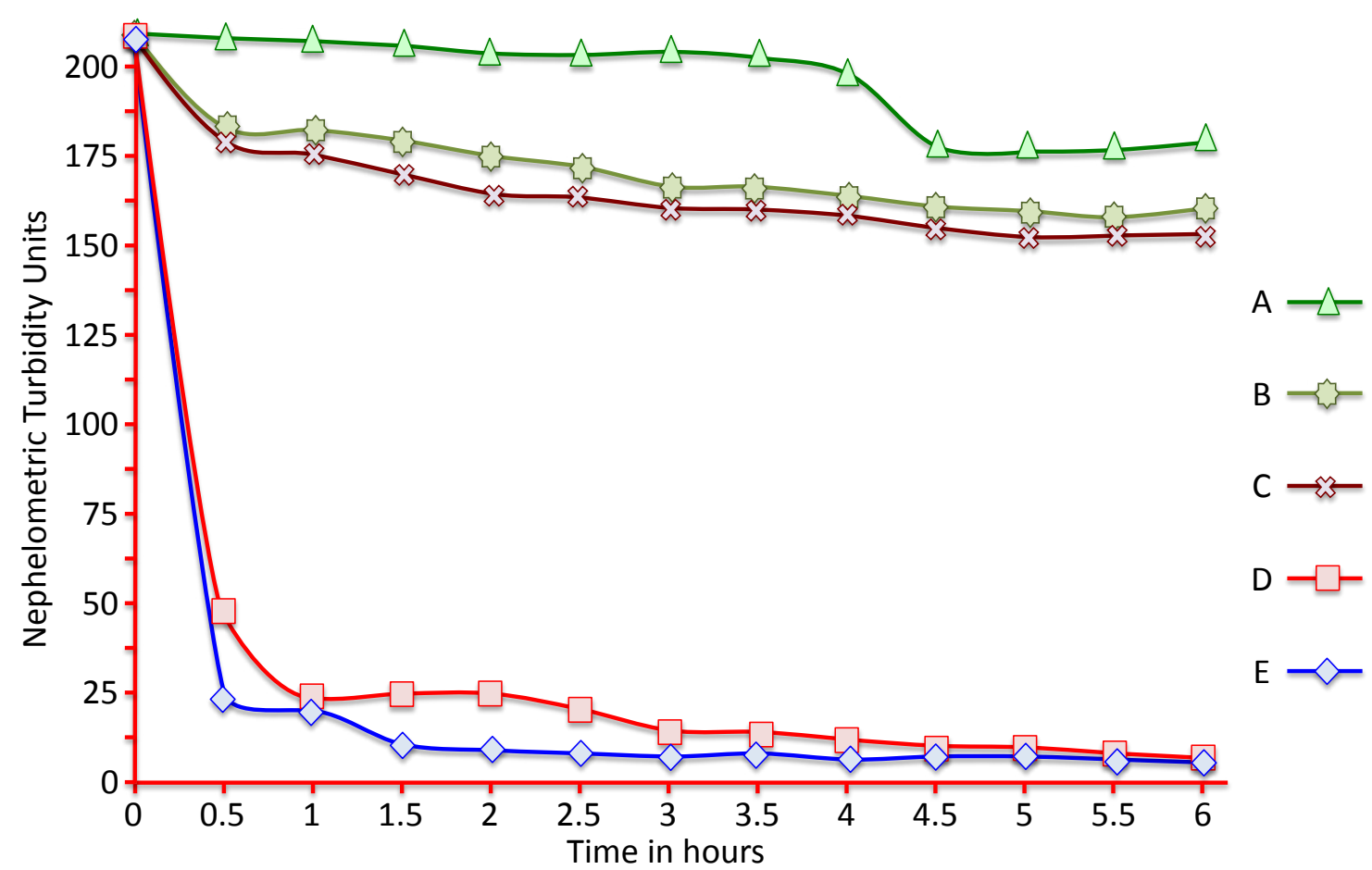

Figure 8. Coagulation test for removal of turbidity (initially 209 NTU) using a control (A) and four plants: (B) Sansevieria forskaliana (Schult. \& Schult.f.) Hepper \& J.R.I.Wood, (C) Sansevieria ehrenbergii Schweinf. ex Baker, (D) Moringa stenopetala (Baker f.) Cufod., and (E) Maerua subcordata (Gilg) DeWolf.

treatment technology widely used by local people living in different parts of the developing world (Clasen et al. 2008, Nare et al. 2013, Nyong \& Kanaroglou 2001). Mostly fuel wood is used for boiling, and this cannot be environmentally friendly as it is the major cause of deforestation as well as a contributor to greenhouse gas emission (Clasen et al. 2008).

Providing microbially safe drinking water is an important public health issue, and the use of chemical disinfection in the $20^{\text {th }}$ century is rightly regarded as a major public health triumph. However, chemical disinfection has also produced an unintended health hazard such as the potential for cancer and other reproductive or developmental effects that may be linked to chemical disinfection byproducts (DBPs) produced during water treatment (Richardson 2005). There is substantive toxicological evidence that DBPs have the potential for inducing adverse health effects (Bull 1985). Using natural products for water treatment (such as documented in the study area) potentially reduces the formation of disinfection by-products ( $\mathrm{Ge}$ bremichael et al. 2005, Grabow et al. 1985).

\section{Plants used for water treatment in the study areas}

Local people in different parts of the world also use different plant species to treat turbid water. For instance, in Tanzania the seed powder from Vigna unguiculata (L.) Walp., Vigna subterranea (L.) Verdc., Arachis hypogaea L., Vicia faba L., and Parkinsonia aculeata L. is used to treat turbid water (Marobhe et al. 2007). Cactus laniferus (J.M. Coult.) Kuntze and Prosopis juliflora (Sw.) DC. are used by people of Venezuela (Diaz et al. 1999). Women in rural areas of Sudan and India use the seed of Moringa to treat drinking water (Jahn \& Dirar 1979, Saif et al. 2012).

\section{Plants used}

Maerua subcordata grows well at altitudes of 500-800 m.a.s.l. Since it grows abundantly in the wild, the plant is not cultivated yet. The tuber of the plant is widely used for water treatment in Jinka and Konso districts. While the plant has one big tuber that can be used for water treatment, it also has numerous small tubers that can grow independent shrubs. Consequently, removing the big tuber will not harm the plant survival. One study in Kenya has 


\section{Megersa et al. - Ethnomedicinal Knowledge on Water Purification in Selected 401 Rural Areas of Ethiopia}

indicated that local people use $M$. subcordata for purification of turbid water (Mavura et al. 2008). The tuber of the plant is also reported to be used for sorption of $\mathrm{Cu}$ (II) and $\mathrm{Pb}$ (II) (Kowanga et al. 2012). Unlike in the study area, the fruit of $M$. subcordata is consumed by local people at the Lower Omo River Valley of Ethiopia during time of scarcity and plenty (Teklehaymanot \& Giday 2010). In Kenya, the leaf is also reported to be used as a fodder (Ida 2005).

Moringa stenopetala is reported to also be used for treatment of malaria and diabetes (Jahn 1991). It is also considered as an underutilized plant species (YDAO 2012). Although the seed is an excellent source for edible oil production, it is not yet utilized in Ethiopia. The plant is not widely used for water treatment; however, in some areas rural people know very well about the water purifying capacity of the powdered seed. As the oil is not useful for water treatment, there is no conflict with food security to use this plant for water treatment.

Sansevieria ehrenbergii is used by local people in various parts of the world for different purposes. For example, the plant is used to treat wounds, for tying, construction, and washing utensils in Kenya (Khalumba et al. 2005). Sansevistatin is one saponin derivative isolated from the plant reported to cause inhibition of cancer cell growth and also exhibit antimicrobial activity (Al-Fatimi et al. 2007, Pettit et al. 2005). The plant is also reported to be used for removal of toluene and ethylbenzene (Sriprapat et al. 2014).

\section{Preparation of plant coagulants}

Local knowledge of mixing coagulants with turbid water followed by settlement is also reported elsewhere (Marobhe et al. 2007). The process is similar to conventional surface water treatment processes and can therefore be simulated using a jar test to determine the coagulant optimum dose (Gregor et al. 1997).

\section{Evaluation of coagulation activity}

Among the four coagulants, $M$. subcordata and $M$. stenopetala were more effective in removing turbidity from natural surface water compared to $S$. ehrenbergii and $S$. forskaliana. A better coagulant efficiency was observed at high turbidity level (209 NTU) when compared to low (26 NTU) and medium (63 NTU) turbidities. Kihampa et al. (2011) also reported that the performance of Solanum incanum L. was much better at high turbidity than low and medium turbidity levels. Therefore, purification of the applied plant material is crucial to reduce the dose needed as coagulant and to enhance the efficiency of plant species at lower turbidities (Ndabigengesere et al. 1995).

\section{Conclusions}

From the traditional medicinal plants that were harvested from the wild, Maerua subcordata and Sansevieria forskaliana were reported to be more effective in treating turbid water. The traditional knowledge and laboratory experiment were in agreement in that all plant types reduced turbidity, but $M$. subcordata tubers were found to be the best natural coagulant. About $98 \%$ turbidity removal efficiency was observed at medium and high turbidity by $M$. subcordata. Detailed analysis is recommended for both $M$. subcordata and $M$. stenopetala of which the latter is less preferred but equally efficient. Integration of indigenous knowledge with scientific experimental approaches will be the best approach for identification of plant-based coagulants that can be easily applied as a low-cost pointof-use water treatment.

\section{Acknowledgments}

We are very much grateful to the financial and logistic support provided by International Foundation for Science (IFS, W/5406-1) and the Ethiopian Ministry of Water and Energy. Moreover, local people of the study area are gratefully acknowledged for sharing their knowledge with us.

\section{Literature Cited}

Al-Fatimi, M., M. Wurster \& G. Schroder. 2007. Antioxidant, antimicrobial and cytotoxic activities of selected medicinal plants from Yemen Ulrike Lindequist. Journal of Ethnopharmacology 111:657-666. dx.doi.org/10.1016/j. jep.2007.01.018

Berkes, F., J. Colding \& C. Folke. 2003. Navigating Social-Ecological Systems: Building resilience for complexity and change. Cambridge University Press, Cambridge, U.K.

Bull, R.J. 1985. Carcinogenic and mutagenic properties of chemicals in drinking water. Science of the Total Environment 47:385-413. dx.doi.org/10.1016/0048$\underline{9697(85) 90344-4}$

Cheserek, G. 2005. Indigenous knowledge in water and watershed management: 'Marakwet' conservation strategies and techniques. FWU Water Resource Publications 3:25-33.

Clasen, T.F., D.H. Thao, S. Boisson \& O. Shipin. 2008. Microbiological effectiveness and cost of boiling to disinfect drinking water in rural Vietnam. Environmental Science and Technology 42(12):4255-4260. dx.doi.org/10.1021/ es7024802 
Cotton, C.M. 1996. Ethnobotany: Principles and applications. John Willey and Sons Ltd., Chichester, U.K.

CSA. 2006. Ethiopia Demographic and Health Survey. Central Statistical Agency, Addis Ababa, Ethiopia.

CSA. 2007. National Population and Housing Survey. Central Statistical Agency, Addis Ababa, Ethiopia.

DHO. n.d. Unpublished reports on diseases in each district as reported through district health offices in Arbaminch Jinka, Konso, and Yabello districts, Ethiopia.

Diaz, A.N., A. Rincon, N. Escorihuela, E. Fernandez, C.F. Chacin \& A. Forster. 1999. A preliminary evaluation of turbidity removal by natural coagulants indigenous to Venezuela. Process Biochemistry 35:391-395. dx.doi. org/10.1016/S0032-9592(99)00085-0

Ellen, R. \& H. Harris. 2000. Introduction. Pp. 1-33 in Indigenous Environmental Knowledge and its Transformations: Critical anthropological perspectives. Edited by R.F. Ellen, P. Parkes \& A. Bicker. Harwood Academic Publishers, Amsterdam, The Netherlands.

Fahey, J. 2005. Moringa oleifera; A review of the medical evidence for its nutritional therapeutic and prophylactic properties Part 1. Trees Life Journal 1:5.

Gebremichael, K.A., K.R. Gunaratna, H. Henriksson, B. Harry \& D. Gunnel. 2005. A simple purification and activity assay of the coagulant protein from Moringa oleifera seed. Water Research 39:2338-2344. dx.doi.org/10.1016/j.watres.2005.04.012

Grabow, W., J.L. Slabert, W.S.G. Morgan \& S.A. Jahn. 1985. Toxicity and mutagenicity evaluation of water coagulated with Moringa oleifera seed preparations using fish, protozoan, bacterial, coliphage, enzyme, and Ames Salmonella assays. Water SA 11:9-14.

Gregor, J.E., C.J. Nokes \& E. Fenton. 1997. Optimizing natural organic matter removal from low turbidity waters by controlled $\mathrm{pH}$ adjustment of aluminum coagulation. Water Research 31:2949-2958. dx.doi.org/10.1016/ S0043-1354(97)00154-1

Ida, W. 2005. The Role of Indigenous Knowledge in Forest Management: A case study from Masol and Sook Division, West Pokot, Kenya. M.Sc. thesis. Swedish University of Agricultural Sciences, Uppsala, Sweden.

Jahn, S.A.A. \& H. Dirar. 1979. Studies on natural water coagulants in the Sudan with special reference to Moringa oleifera seeds. Water SA 5(2):90-97.
Jahn, S.A.A. 1991. The traditional domestication of a multipurpose tree Moringa stenopetala (Bak.f.) Cuf. in the Ethiopian Rift Valley. Ambio 20(6):244-247.

Khalumba, M.L., P.K. Mbugua \& J.B. Kung'u. 2005. Uses and conservation of some highland species of the genus Sansevieria Thunb. in Kenya. African Crop Science Conference Proceedings 7:527-532.

Kihampa, C.W., M.M. Kaseva \& N. Marobhe. 2011. Performance of Solanum incunum L. as natural coagulant and disinfectant for drinking water. African Journal of Environmental Science and Technology 5:867-872.

Kowanga, K.D., E. Gatebe \& P. Kareru. 2012. Bio sorption of $\mathrm{Cu}(\mathrm{I} \mathrm{I})$ and $\mathrm{Pb}(\mathrm{I} \mathrm{I})$ using Maerua subcordata root tubers. TAJONAS 1(3):439-452.

Marobhe, N.J., G. Renman \& G. Jacks. 2007. The study of water supply and traditional water purification knowledge in selected rural villages in Tanzania. Pp. 111-120 in Indigenous Knowledge Systems and Sustainable Development: Relevance for Africa. Edited by E.K. Boon \& L. Hens. Kamla-Raj Enterprises, Delhi, India.

Martin, G.J. 1995. Ethnobotany: A methods manual. Chapman and Hall, London, U.K. dx.doi.org/10.1007/9781-4615-2496-0

Mavura, W.J., M.C. Chemelil, W.W. Saenyi \& H.K. Mavura. 2008. Investigation of chemical and biochemical properties of Maerua subcordata plant extract: A local water clarification agent. Chemical Society of Ethiopia 22(1):143-148.

Megersa, M., A. Beyene, A. Ambelu \& B. Woldeab. 2014. The use of indigenous plant species for drinking water treatment in developing countries: A review. Journal of Biodiversity and Environmental Sciences 5(3):269-281.

Miller, S.M., E.J. Fugate, V.O. Craver, J.A. Smith \& J.B. Zimmerman. 2008. Toward understanding the efficacy and mechanism of Opuntia spp. as a natural coagulant for potential application in water treatment. Environmental Science and Technology 42:4274-4279. dx.doi. org/10.1021/es 7025054

Nare, L., J.O. Odiyo, F. Ravululu \& N Potgiete 2013. Evaluation of community knowledge, attitudes, practices and perceptions relating to water quality and safety in Luvuvhu catchment of South Africa. Journal of Environmental Sciences and Water Resources 2(3):67-74.

Ndabigengesere, A., K.S. Narasiah \& B.G. Talbot. 1995. Active agents and mechanisms of coagulation of turbid water using Moringa oleifera. Water Research 29(2):703710. $\mathrm{dx}$.doi.org/10.1016/0043-1354(94)00161-Y 


\section{Megersa et al. - Ethnomedicinal Knowledge on Water Purification in Selected 403 Rural Areas of Ethiopia}

Nyong, A.O. \& P.S. Kanaroglou. 2001. A survey of household domestic water-use patterns in rural semi-arid Nigeria. Journal of Arid Environments 49:387-400. dx.doi. org/10.1006/jare.2000.0736

Pettit, G.R., Q. Zhang, V. Pinilla, H. Hoffmann, J.C. Knight, D.L. Doubek, J.-C. Chapuis, R.K. Pettit \& J.M. Schmidt. 2005. Antineoplastic agents. 534. Isolation and structure of sansevistatins 1 and 2 from the African Sansevieria ehrenbergii. Journal of Natural Products 68(5):729-733. dx.doi.org/10.1021/np040203r

Pritchard, M., T. Mkandawire, A. Edmondson, J.G. O’Neill \& G. Kululanga. 2009. Potential of using plant extracts for purification of shallow well water in Malawi. Physics and Chemistry of the Earth 34:799-805. dx.doi.org/10.1016/j. pce.2009.07.001

Raedeke, A.H. \& J.S. Rikoon. 1997. Temporal and spatial dimensions of knowledge: Implications for sustainable agriculture. Agriculture and Human Values 14:145-158. dx.doi.org/10.1023/A:1007346929150

Richardson, S.D. 2005. New disinfection by-product issues: Emerging DBPs and alternative routes of exposure. Global NEST Journal 7(1):43-60.

Saif, M.M.S., N.S. Kumar \& M.N.V. Prasad. 2012. Binding of cadmium to Strychnos potatorum seed proteins in aqueous solution: Adsorption kinetics and relevance to water purification. Colloids and Surfaces B 94:73-79. dx.doi.org/10.1016/j.colsurfb.2012.01.039

Shultz, C.R. \& D.A. Okun. 1984. Surface Water Treatment for Communities in Developing Countries. John Wiley and Sons Inc., London, U.K.
Sriprapat, W., P. Suksabye, S. Areephak, P. Klantup, A. Waraha, A. Sawattan \& P. Thiravetyan. 2014. Uptake of toluene and ethylbenzene by plants: Removal of volatile indoor air contaminants. Ecotoxicology and Environmental Safety 102:147-151. dx.doi.org/10.1016/j. ecoenv.2014.01.032

Sutherand, J.P., G.K. Folkard \& W.D. Grant. 1989. Seeds of Moringa species as naturally occurring flocculants for water treatment. Science Technology Development 7:191-197.

Teklehaymanot, T. \& M. Giday. 2010. Ethnobotanical study of wild edible plants of Kara and Kwego semi-pastorialist people in lower Omo River valley, Debud Omo Zone, SNNPR, Ethiopia. Journal of Ethnobiology and Ethnomedicine 6:23. dx.doi.org/10.1186/1746-4269-6-23

UNICEF/WHO. 2012. The United Nations Children's Fund/World Health Organization. Joint Monitoring Programme for Water Supply and Sanitation. Estimates for the use of improved drinking water sources Ethiopia. www.wssinfo.org.

YDAO. 2012. Annual Report on Cultivation of Moringa. Yaballo District Agricultural Office, Yaballo, Ethiopia.

Yongabi, K.A., D.M. Lewis \& P.L. Harris. 2011. Indigenous plant based coagulants/disinfectants and sand filter media for surface water treatment in Bamenda, Cameroon. African Journal of Biotechnology 10(43):8625-8629. 
